NBER WORKING PAPER SERIES

\title{
INTERNAL FINANCE AND INVESTMENT: EVIDENCE FROM THE UNDISTRIBUTED PROFITS TAX OF 1936-1937
}

\author{
Charles W. Calomiris \\ R. Glenn Hubbard
}

Working Paper No. 4288

\section{NATIONAL BUREAU OF ECONOMIC RESEARCH 1050 Massachusetts Avenue \\ Cambridge, MA 02138 March 1993}

\begin{abstract}
Calomiris is associate professor of finance, University of Illinois and faculty research fellow, National Bureau of Economic Research. Hubbard is professor of economics and finance, Graduate School of Business, Columbia University and research associate, National Bureau of Economic Research. The authors thank Herb Baer, Michael Bernstein, David Cutler, Bruce Meyer, Jay Ritter, and seminar participants at the NBER Conference on Macroeconomic History, Princeton University, the Wharton School, the University of Ilinois, Indiana University, the Boand of Govemors of the Federal Reserve System, the Bank of Norway, and the Federal Reserve Banks of Chicago, New York, Philadelphia, and Richmond for helpful comments. This paper is part of NBER's research program in Corporate Finance. Any opinions expressed are those of the authors and not those of the National Bureau of Economic Research.
\end{abstract}


NBER Working Paper \#4288

March 1993

\title{
INTERNAL FINANCE AND INVESTMENT: EVIDENCE FROM THE UNDISTRIBUTED PROFITS TAX OF 1936-1937
}

\begin{abstract}
Recent theoretical approaches have linked shifts in firms' internal funds and investment spending, holding constant underlying investment opportunities. An important impediment to convincing tests of these models is the lack of firm-level data on the relative costs of internal and external funds. We use a tax experiment, the Surtax on Undistributed Profits (SUP) in the 1930s, to identify firms' relative cost of internal and external funds and analyze its effect on firms' investment decisions. Firms' responses to the surtax on retained eamings permit estimation of shadow price differentials between internal and external finance, and measurement of the link between access to capital markets and investment.

Almost one-fourth of the 273 publicly-traded manufacturing firms in our sample retained in excess of 40 percent of their earnings in spite of the surtax, paying the highest marginal rates of surtax. The investment spending of these firms was sensitive to shifts in cash flow, holding constant investment opportunities (measured by the ratio of market-to-book value). No sensitivity of investment to internal funds could be detected for firms with higher dividend payout and lower surtax liability. In addition, many firms with high marginal rates of surtax were in the growth industries of the day. The sensitivity of investment spending to internal funds for firms with high marginal surtax rates appears mainly to reflect information-related capital-market frictions as opposed to the waste of corporate cash flows by entrenched managers.
\end{abstract}

Charles W. Calomiris

Department of Finance

University of Illinois

340 Commerce West

Champaign, IL 61820 and NBER
R. Glenn Hubbard

Graduate School of Business

Columbia University

Uris Hall 609

New York, NY 10027

and NBER 


\section{INTRODUCTION}

Recent theoretical work on the financing of investment under asymmetric information has emphasized the existence of a shadow price differential between internal finance (retained eamings) and external finance (debt and stock flotations). "Lemons" premia in equity markets (as in Myers and Majluf, 1984), and credit rationing or loan mispricing (as in Jaffee and Russell, 1976; Stiglitz and Weiss, 1981; Gale and Hellwig, 1985; Williamson, 1986; Bernanke and Gertler, 1990; and Calomiris and Hubbard, 1990) imply that external finance will be more costly than internal finance (for a review see Gertler, 1988). Moreover, the shadow price differential between internal and external finance will vary across firms depending on the relative degree of information asymmetry, and differences in simple transacting costs. Recent empirical research using data from the post-World War II period has found much evidence for the importance of this cost wedge between internal and external finance in explaining firm heterogeneity in investment behavior, and aggregate sensitivity of investment to cash flow (see Fazzari, Hubbard, and Petersen, 1988; Hoshi, Kashyap, and Scharfstein, 1991; Whited, 1990; Himmelberg, 1990; and Gilchrist, 1990). This new body of theoretical and empirical work has formalized and quantified arguments which have a long history in the investment literature (see Butters and Lintner, 1945; and Meyer and Kuh, 1957).

In this paper, we employ a new firm-level data set to measure the importance of the shadow price differential between internal and external finance for explaining investment of U.S. manufacturing firms during the rapid recovery, and subsequent recession, of 19331938. Our data allow us to investigate the effects of financial constraints on firm growth during the expansion, and to take advantage of the heterogeneity in our sample to discover 
which firms were most sensitive to cash flow disturbances (changes in the supply of internal finance).

What has been lacking in existing studies using firm-level data is a firm-level index of the marginal costs of external finance. For example, studies using the Q-theory approach model investment as being determined by beginning-of-period $Q$ (to control for investment opportunities) and a measure of internal funds. For firms with high costs of borrowing (due to asymmetric information between insiders and outsiders regarding firm prospects), investment will exhibit excessive sensitivity to cash flow, holding $Q$ constant. ${ }^{\prime}$ In existing studies low initial dividend payout ratios or small firm size are typically used as proxies for high costs of external finance. In this paper, we are able to estimate the costs of external finance directly by examining firms' responses to a unique tax "experiment" in U.S. history, the Undistributed Profits Tax (or Surtax on Undistributed Profits) of 1936-1937.2 This tax was a surtax on corporate retentions over and above normal corporate taxes. Because the maximum marginal tax rate was 27 percent, most firms had large incentives to change their payout policies. Working against this response for some firms is the potential difference in the cost of internal and external funds. To the extent that the marginal cost of external funds is high, a growing firm with profitable investment opportunities might choose to pay the undistributed profits tax and invest its internal funds, rather than distribute funds and then reacquire them in the capital market. Under certain assumptions, the observed undistributed profits tax payments for such firms can be used to approximate the differential cost of external finance, and variation in the response to the tax across firms can be related to variations in investment behavior. ${ }^{3}$ 
Our study of the undistributed profits tax, and its implications for measuring the costs of external finance, is also motivated by a specific interest in the macroeconomic events of the 1930s. The timing of the undistributed profits tax experiment is fortuitous, since the protracted recovery from the Great Depression has been attributed by Fisher (1933) and Bemanke (1983) to increases in the costs of external finance. Bernanke stressed increases in the "cost of credit intermediation" which resulted from deflation-induced reductions in firms" net worth (which reduced firms' creditworthiness in the presence of leverage constraints), and the weakening and partial destruction of the banking system from 1930 to 1933 . Bemanke points to time-series evidence of links between credit supply shocks (deflation and default premia) and investment, and to the large excess reserve holdings of commercial banks to argue for the importance of credit constraints in limiting investment. Clearly, a crosssectional analysis of the role of external finance constraints in determining investment would provide the perfect test of the importance of credit costs, as described by Fisher and

\section{Bemanke."}

Section II reviews the history of the surtax on undistributed profits, describes its incidence on firms of different sizes, and explains our method for identifying the marginal cost differential between external and internal finance. Section III describes our dataset. In section IV, we provide some basic summary statistics on the characteristics of firms with high costs of external finance, as measured by undistributed profits tax margins. We argue that the differences between firms with high and low costs of external finance mainly reflect information-related capital-market frictions as opposed to the waste of corporate cash flow by entrenched managers. Section $\mathrm{V}$ reports regression results relating investment behavior 
(particularly cash-flow sensitivity) to differences in the costs of external finance. We find that a neoclassical investment model with no explicit capital-market frictions cannot be rejected except for firms with high surtax margins. The investment spending of those firms displayed excess sensitivity to internal funds. In addition, working capital accumulation was responsive to cash flow only for high-tax margin firms, suggesting the use of working capital to smooth fixed capital investment when external finance is costly. In section VI, we show that industries with the highest proportions of firms with high tax margins were among the fastest growing of the day. Section VII concludes.

\section{MEASURING FINANCE COSTS USING UNDISTRIBUTED PROFIT TAX MARGINS}

\section{A. The Tax Experiment}

The surtax on undistributed profits (SUP) was created to restrict corporate discretion over retained earnings. Unlike the current accumulated earnings tax the SUP taxed all of retained earnings, including funds used to finance investment projects. By taxing retained earnings it was thought that firm managers would be forced to face the discipline of the capital market to finance their investments, thus making the capital allocation process more efficient (see Berle and Means, 1932, Tugwell, 1933, Hazelett, 1936, and Buehler, 1937). ${ }^{\mathrm{s}}$ The logic of this argument is quite similar to recent theoretical models of "free cash flow" that emphasize potential agency problems between management and shareholders of mature firms (for example, Easterbrook, 1984, and Jensen, 1986).

The Surtax on Undistributed Profits appears to have been unanticipated (see the discussion in Blakey and Blakey, 1936). No reference was made to it in President 
Roosevelt's budget messages of June 1935 or January 1936. The proposal was presented by the President in a special message to Congress on March 3, 1936, in which he announced the need for the tax as a revenue-raising device. Strong opposition by key Congressional factions and lobbying efforts by business groups to repeal the surtax led to early amendment and repeal of the surtax. The surtax survived in its original form through 1937. By 1938, legislative amendments reduced substantially the effective surtax rate. The tax expired formally in December 1939, in accordance with the Revenue Act of 1938. At the time, most observers seemed to agree that the tax had a significant effect on dividend payouts only in 1936 and 1937 (see Thorp and George, 1937; Kendrick, 1937; and Lent, 1948).

The Roosevelt Administration proposed the SUP as a substitute for the corporate income $\operatorname{tax}$ (which would have avoided the double taxation of dividends), but Congress added it to the existing corporate tax as a surtax on retained earnings. From the beginning there were protests against the tax, particularly from small, growing enterprises. These firms complained that the tax discriminated against growing firms with high costs of external finance. Responses to a Brookings Institution survey of firms in 1937 (Kendrick, 1937) contained many such complaints. In one case a large, dominant firm noted that it had gained a competitive advantage as the result of its low financing costs, given the greater incidence of the tax on its smaller and younger competitors. The large firm (perhaps uncharacteristically) argued that this was an unfair advantage and suggested repeal of the tax. Many annual corporate reports for 1936 contained special statements discussing and criticizing the new tax. As a result of these protests the tax was repealed in 1938 (see also Lent, 1948; and Dobrovolsky, 1951). 
The computation of a firm's SUP liability followed a simple rule. The marginal tax rate was progressive as a function of the percentage of earnings retained out of corporate income (after subtracting regular corporate income tax paid). On the first 10 percent of earnings retained a firm would pay 7 percent of retained earnings in tax. On the next 10 percent it would pay 12 percent of retained earnings. On retentions of between 20 and 40 percent of income a 17 percent marginal tax rate applied. For retentions between 40 and 60 percent of income a 22 percent marginal tax rate was charged. On all retentions above 60 percent of income the marginal tax rate was 27 percent. There were special exemptions (for example, for firms with bond covenants that restricted dividend payments), and there was a small tax credit for firms earning less than $\$ 50,000$ in income.

The maximum marginal tax rate paid by a firm provides a measure of the shadow price differential between external and internal finance costs, once one takes proper account of the tax consequences of dividends and retentions. In the Appendix, we provide a method for approximating the shadow price differential using the firm's maximum tax margin and information on the tax rates applied to dividends and capital gains. For example, a firm at the 27 percent margin paying near-zero dividends and seeking to finance new investment projects was willing to pay 27 cents to avoid having to raise 73 cents in outside funds. We estimate the shadow cost differential for such a firm (in present value terms) was likely in excess of 25 percent.

Given the avoidability of the tax through dividend payments, one might expect that little revenue was actuaily raised by the tax, and that very few firms paid the highest marginal rates. While it is true that the vast majority of firms increased dividend payout rates in 1936 
to limit their tax liability under the new law, a substantial number of firms paid high marginal SUP rates, and the revenue from the new tax was large. The SUP earned $\$ 145$ million in revenue in 1936 and $\$ 176$ million in 1937, compared to regular corporate tax earnings of $\$ 950$ million and $\$ 1,150$ nillion for 1936 and 1937 , respectively. As Table 1 shows, retained earnings as a percentage of after-tax income fell from 1935 to 1936 most dramatically for the largest firms in the economy. The average retention ratio for all firms fell from 23 percent to 15.1 percent. For firms with assets of greater than $\$ 50$ million the mean retention ratio fell from 19.8 percent to 4.9 percent. Mean retention ratios in 1936 decline with firm size, rising from 4.9 percent for the largest firms to 35.8 percent for the smallest.

Table 2 provides complementary evidence on the distribution of highest marginal rate paid on the SUP, conditioning on the size of firms measured by income. For firms earning profits (and hence subject to the surtax) a substantial fraction paid marginal tax rates of 22 or 27 percent. Firms with very low incomes (less than $\$ 10,000$ ) avoided high tax margins mainly by applying the special tax credit available to firms with income less than $\$ 50,000$. The very largest firms also avoided the highest tax brackets, presumably because of their lower costs of external finance. However, for income classes between $\$ 10,000$ and $\$ 1$ million, between 17 and 23 percent of firms paid marginal rates of 22 or 27 percent, with roughly 10 percent of firms in the 27 percent bracket. The concentration of high margins in middle-income ranges may also be due to differences across firm sizes in the ability of firms to reduce measured profits by adjusting the salary-profit mix of entrepreneur-managers, 
which was especially relevant for very small firms (see Thorp and George, 1937, and Dobrovolsky, 1951).

\section{B. Direct Evidence of Costly External Finance in the 1930s}

Independent evidence from surveys by the Securities and Exchange Commission (1941a, 1941b) on the cost of common stock flotation confirms that costs of issuing securities in the 1930 s often were large. For example, as reported in Table 3, for a sample of 64 firms with assets of under $\$ 5$ million average costs of flotation ranged between 20 and 27 percent of the value of the amount of common stock issued. Physical expenses accounted typically for costs of 2 or 3 percent. The remainder was paid as compensation to the intermediary who handled the issue. Underwriting insurance costs do not account for the bulk of this fee. In 1938 underwritten common stock issuers paid an average compensation of 17.5 percent of the issued amount to brokers, while nonunderwritten common stock issuers paid 19.1 percent on average. Recent models of information production by securities intermediaries may help explain such high fees. According to Benveniste and Spindt (1989), for example, costs of public stock brokerage reflect substantial costs of gathering information. ${ }^{6}$

The view that costs of finance mainly reflect information costs is supported further by comparing the broker's compensation on preferred stock and bonds with those on common stock. Compensation for preferred stock and bonds sold to the public was substantially lower than for common stock, and as before, was highest for nonunderwritten issues. For example, nonunderwritten preferred stock compensation to brokers on public issues averaged 12.2 percent in 1938 for 31 issues, compared to a 2.7 percent average for 12 underwritten issues. For bond issues, brokers' compensation and physical expenses were roughly 
comparable and together small in comparison to stock issue costs. These findings show that firms faced substantially different marginal costs of finance in markets for different types of securities. In equilibrium, low-cost forms of finance were rationed to certain firms. ${ }^{7}$ Comparisons of commissions across issues (Mendelson, 1967) and across investment banking regimes (Calomiris, 1992) confirm the positive association between information costs and commissions.

In summary, SEC data on the measured costs of public securities issues support the evidence in Table 2 that a substantial number of firms faced a shadow price differential between extemal and internal funds in excess of 20 percent. Furthermore, differences in costs of finance across securities lend support to theoretical models of credit or equity rationing based on asymmetric information, which are consistent with such market segmentation.

\section{THE DATA}

We constructed a firm-level data set combining information on income, investment, financial structure, dividend payout, firm market values, and SUP margins for as many firms as possible during the period of recovery from the Great Depresion. An extremely valuable primary source for firm-level data for our period is the Survev of Listed Corporations, which summarizes data submitted to the Securities and Exchange Commission for all publicly traded firms. These data include detailed information from balance sheets, income and expense statements, and records of dividend distributions. 
Five hundred twenty-eight manufacturing firms appear in the Survey dataset, which covers the years 1934-1938 (with some limited coverage of 1939). Many of these firms, however, did not report consistent data for the period 1935-1937, and hence were excluded from the dataset. Other firms were excluded because they did not earn positive profits in 1936, and therefore, were not subject to the SUP. Still other firms were eliminated because stock price data were not available (from other sources noted below) for 1935 or 1936 , or because taxation and dividend data were insufficient to calculate the maximum marginal rate of the SUP. These various deletions left us with 273 firms.

The principal source for data on SUP taxes and dividends was Moody's Industrial Manual (various years). In calculating dividends it was crucial to know precisely when dividends were paid, since only dividends paid within the calendar year reduced liability for the SUP. Furthermore, stock dividends which were not bona fide disbursements of funds did not reduce SUP liability, so it was important to distinguish dividends by type. Moody's was also a useful source of information on bond covenants; in a few cases, covenants restricting dividends paid (which were allowed by the SUP as an exemption to the tax) resolved seeming anomalies between the amount of SUP paid and the amount of tax liability implied by retained eamings. Where Moody's did not report data on SUP taxes paid we referred to individual annual reports of corporations at the Stanford Business School Library, which accounted for roughly half of our data on SUP payments.

There are three ways to calculate a firm's maximum margin for the SUP. One needs any two of the following pieces of information to calculate the marginal tax rate: income, dividends, and SUP payments. To insure against error, we performed the calculations all 
three ways where possible. If any methods led to contradictory results, we went back to Moody's and the annual reports to resolve the differences. If differences could not be resolved, we dropped the firms. In a few cases, SUP payment data were not available even though all other data were. For these firms, margins were inferred from data on dividends and income, and cross-checked with total corporate tax payments to ensure consistency as best we could. We then estimated the models described in section IV with and without these firms. The presence or absence of these firms made no difference for any of our results, except improving our sample size and standard errors, so we included them in our sample of 273 firms.

To construct our measure of firm market values we collected end-of-year price data for common and preferred stocks for 1935 and 1936 from the Wall Street Joumal, and supplemented these price data, where necessary, with data from other newspapers and from Moody's. If it was not possible to gauge stock prices accurately (if reported ranges of values were large) we dropped the firm. Based on a preliminary analysis of bond price data, and on some difficulties disentangling bond aggregates from other forms of debt, we decided to value all debt at its face value. The small proportion of debt finance for most firms (and much smaller proportion of bonds), along with the fact that bonds traded very near par for the firms that issued bonds, imply that valuing debt at face value is unlikely to generate any important bias. Quantities of each stock of each class were taken from Moody's.

One limitation of our data is the definition of investment. Our measure of investment is the change in the book value of fixed capital (land, buildings, and equipment). Unfortunately, gross investment data are not reported by firms. While capital stock data are 
not ideal for our purposes because of possible idiosyncrasies in the measurement of depreciation, we think the strength and robustness of the net investment regressions we report argue for treating the change in book capital as a reasonable measure of investment. ${ }^{9}$

\section{CHARACTERIZING FIRMS WITH HIGH COSTS OF EXTERNAL FINANCE}

In this section, we describe some of the salient characteristics of firms with different extemal finance costs as measured by the maximum marginal rate on the SUP. These descriptions are useful for two reasons. First, such a description can suggest whether previous empirical studies have been correct to associate low dividend payout and small firm size with high costs of external finance. Our direct measures of external finance costs permit us to test the assumptions of these studies.

Second, the characteristics of finance-constrained firms can help one to distinguish between two altemative explanations for high external finance costs which have different positive and normative implications. The first explanation points to asymmetry of information between insiders and outsiders about firm opportunities. This limits the supply of funds available to some firms, as described in Stiglitz and Weiss (1981), Myers and Majluf (1984), Bernanke and Gertler (1989), and Calomiris and Hubbard (1990). The firms most affected presumably would be small, growing enterprises in developing industries. Increases in internal net worth for this group of firms would have allocative benefits (Calomiris and Hubbard, 1990).

An alternative explanation for high costs of external finance focuses instead on the agency problem between managers and their stockholders, following the logic of Berle and 
Means (1932), Tugwell (1933), Easterbrook (1984), and Jensen (1986). In mature enterprises for which investment opportunities on the margin are no longer promising, managers may over-invest available "free cash flow." External finance is costly, not because of adverse selection, but because outside investors are unwilling to finance low-quality projects. Managers may prefer over-investment, when possible, because it permits management to capture rents at the expense of stockholders. For example, according to this "entrenched management" view, firms with greater costs of removing or disciplining managers will tend to be the high-finance-cost firms. For these enterprises increased cash flow will have adverse allocative consequences. The "entrenched management" explanation for high costs of finance is especially important to consider in our study, since it was central to the rationale given for the SUP by its proponents. An important benefit of the tax was supposed to be the elimination of the rents of entrenched management.

These alternative interpretations of high costs of external finance imply different characteristics of firms with high financing costs. According to the asymmetric information view, the quintessential high-surtax-margin firm would be a small, growing enterprise in a new industry. According to the entrenched management view, high-surtax-margin firms would tend to be large, mature firms in sunset industries with declining investment opportunities.

In the tables that follow, we divide firms into three categories, based on their maximum SUP margins in 1936: firms with a 12 percent or lower maximum marginal rate; firms with a 17 percent marginal rate; and firms with a 22 or 27 percent marginal rate. These divisions correspond to retention rates in 1936 of less than 20 percent (Type A), 20-40 percent (Type 
B), and greater than 40 percent (Type C). By grouping firms into three categories, we economize on space and obtain large enough numbers of firms in each category to facilitate statistical inference. ${ }^{10}$ The results we report do not differ qualitatively if we used all five categories rather than the three used here. Our smallest cell contains the 66 firms in the highest-surtax-margin group (Type $\mathrm{C}$ firms), which are roughly evenly divided between those with maximum margins of 22 percent and 27 percent. The distribution of firms in different types closely parallels that of Table 2 for firms of comparable size, except that Type B firms are somewhat over-represented, and Type A firms somewhat under-represented in comparison to the cells in Table 2. In our sample, Type A firms account for 47 percent, Type B firms 29 percent, and Type C firms 24 percent.

In Tables 4 through 9 , we report means, medians, standard deviations, and numbers of firms in each category for various firm characteristics including firm size (total assets in 1936), profit rates (operating profits less interest payments divided by book-value net worth), the change in operating profits divided by assets, net operating profits relative to sales, the ratio of market to book value and its percentage change, and dividend payout for each type. These data highlight interesting characteristics of high-finance-cost firms, and help to discriminate between the two views of the motives behind costly retentions of profits. Table 10 provides supplementary data on median standard errors and the statistical significance of differences in medians between Type $A$ and Type $C$ firms. Tests of differences across medians are not as sensitive to outliers as comparable comparisons of differences in means.

Table 4 reports data on dividends as a percentage of after-tax profits in 1935 and 1936 for firms with positive profits. For 1936, type differences in dividend payout are present by 
construction, since low dividend payout determines firm type. For 1935, however, dividend payout was not affected by the SUP. Table 4 shows that dividend payout in 1935 is much lower for firms in higher SUP margins in 1936. The median ratio for Type $C$ firms is 4 percent, compared to 51 percent for Type B firms and 70 percent for Type A firms. This provides some support for the use of dividend payout as a conditioning variable to sort firms according to their costs of external finance, as for example in Fazzari, Hubbard, and Petersen (1988).

Table 5 reports data on firm asset size by type in 1936. As predicted by the financinghierarchy view, smaller firms tend to be the ones with the highest external finance costs. These differences are large and statistically significant (see Table 10). The median firm size for Type $\mathrm{C}$ firms (\$6.4 million in assets) is less than one-half that of Type B, and less than one-third that of Type A. The large standard deviations of firm size in each category, however, indicate that there is substantial overlap in the size distributions of the different types. ${ }^{11}$ Thus firm size may be a very inexact proxy for finance costs.

Table 6 provides data on operating profits less interest divided by net worth for 1936 . Profit rates are similar across types, with Type- $B$ firms showing higher means and medians than Types $\mathrm{A}$ and $\mathrm{C}$, which are roughly identical. This pattern is not consistent with viewing Type C firms' managers as more wasteful in their use of funds, but it could be consistent with the financing-hierarchy view. Large, mature, Type-A firms might be expected to have low average rates of profit, while small growing firms, which are likely to be in the Type $C$ group, may have smaller profits to capital because of their small size and high ratio of fixed to variable costs. According to this interpretation, as firnis progress in the "life cycle" from 
$\mathrm{C}$ to $\mathrm{B}$ to $\mathrm{A}$ their average profits rise and then fall. An additional fact that is consistent with this interpretation is that the procyclical change in profits increases in type. As Table 7 shows, Type B and Type C firms exhibit larger profit growth during the boom year of 1936 , and smaller profit growth in 1937, which saw a cyclical peak in October. Similarly, net operating profits relative to sales in 1936 is lowest for type $C$ firms, and these firms show the greatest change in this ratio from 1935 to $1936 .^{12}$ These differences in medians of profit-to-sales ratios and profit growth are statistically significant, as Table 10 shows.

Table 8 examines the level and growth of the ratio of market to book value. ${ }^{13}$ While mean and median ratios of market to book value are lower in 1936 for Type C firms (a fact consistent with both the asymmetric information and entrenched management views) ${ }^{14}$, the change in the market-to-book-value ratio during 1936 for Type C firms (shown in Table 8) is 37 percent, compared to 15 and 23 percent, repectively, for Type $B$ and $A$ firms. These differences in medians are statistically significant, as shown in Table 10. As Brock and LeBaron (1990) argue, the greater procyclicality of firm valuation for Type C firms is consistent with asymmetric information models of financing constraints (Myers and Majluf, 1984; Gale and Hellwig, 1985; Bernanke and Gertler, 1990; and Calomiris and Hubbard, 1990). Business cycle upswings increase available cash flow (or "financial slack" in the language of Myers and Majluf), which relaxes financing constraints and increases the value of constrained firms. While all firms will experience a rise in value during an expansion, constrained firms stock prices will be more responsive to the cycle. Jog and Schaller (1992) find evidence in support of such a difference in a panel study of Canadian firms. 
In Table 9, we report data on the ratio of debt to the market and book value of equity, respectively. We report data for both 1935 and 1936 to see whether the surtax affected firms' financing decisions. By reducing taxable corporate income, debt finance would have reduced a firm's surtax liability. Interestingly, using market value of equity, mean debt ratios are higher in 1935 than in 1936 for each type, and median debt ratios are higher in 1935 than in 1936 for Type C firms, and differences in medians across types are statistically significant (see Table 10). The lower mean debt ratios in 1936 likely reflect, in part, the growth in stock prices in 1936, along with transactions costs of converting existing equity into debt. Using the debt-to-equity ratios measured in book value, all types show an increase from 1935 to 1936 in mean and median ratios, indicating an increased role for debt on the margin.

An interesting feature of the data reported in Table 9 is the relatively high ratio of debt to the market value of equity in the capital structure of high-surtax-margin firms in 1935 and 1936. One interpretation of the high debt ratios of high-surtax-margin firms is a greater reliance on financial intermediaries, who finance through debt. Financial intermediaries specialize in screening and monitoring borrowers, and therefore have a greater role in financing firms whose prospects are not common knowledge. ${ }^{15}$ More generally, many authors have argued that direct or intermediated debt contracts are likely to arise in environments where asymmetric information about project opportunities or outcomes is important. ${ }^{16}$ In contrast, the literature on managerial entrenchment views debt as a disciplinary device that limits managers ability to extract rents from firms (Jensen, 1986, Hanka, 1992). According to this view, Type-C firms should have had lower debt ratios. 
To summarize, firm-level evidence on size, profitability, profit growth and stock price changes, as well as aggregate data on the high flotation costs of publicly traded securities, all support our focus on capital market frictions arising from asymmetric information as the principal source of high costs of external finance for business fixed investment.

\section{INVESTMENT BEHAVIOR AND COSTS OF EXTERNAL FINANCE}

Following the intuition of Fazzari, Hubbard, and Petersen (1988), we begin our empirical tests for the effects of differentially high costs of external finance on firm investment within the Q-theory approach. ${ }^{17}$ It is well known (see for example Hayashi, 1982) that under assumptions of a constant-retums-to-scale technology and quadratic adjustment costs, the Euler equation for the firm's choice of its capital stock can be solved forward to obtain a linear relationship between the investment rate (investment I divided by the beginning-of-period capital stock $\mathrm{K}$ ) and marginal $\mathrm{Q}$ (using average $\mathrm{Q}$ as a proxy):

$$
(I / K)_{h}=a_{i}+b Q_{i t}+e_{i t}
$$

where $i$ and $t$ denote the firm and time, respectively, a represents the normal or average level of the investment rate, and $b$ is the inverse of the coefficient on the quadratic adjustment cost term. Under the efficient markets hypothesis, Q summarizes market expectations about the profitability of the firm's investment opportunities. $e$ is an expectational error term. In particular, adding extra terms as proxies for internal funds (e.g., anticipated "cash flow") known to the stock market should add no marginal predictive content for investment. That 
is, denoting anticipated "cash flow" (net profit from operations less interest expense and taxes) by CF, one would expect, under the null hypothesis of efficient capital markets and no cost differential between internal and external funds, that the coefficient $c$ in the augmented regression

$$
(\mathrm{I} / \mathrm{K})_{\mathrm{it}}=\mathrm{a}_{\mathrm{i}}+\mathrm{b} \mathrm{Q}_{\mathrm{it}}+\mathrm{c}(\mathrm{CF} / \mathrm{K})_{\mathrm{it}}+\mathrm{e}_{\mathrm{it}}
$$

should be zero. The Fazzari-Hubbard-Petersen approach grouped firms into a priori "constrained" and "unconstrained" sets based on long-run dividend payout patterns, and tested for inter-group differences in the coefficients.

There are potential problems with this simple reduced-form approach, of course, stemming from difficulties in measuring marginal $Q$, identifying $Q$ as a reasonable proxy for "fundamentals" owing to possible lapses of stock market efficiency (see for example Gilchrist and Himmelberg, 1991), and specifying an alternative structural model in which internal net worth variables appear (as in Hubbard and Kashyap, forthcoming). Nonetheless, we feel that significant intuition is gained from the reduced-form approach, given our identification of external finance cost differentials through firm-level responses to the surlax.

The surtax experiment gives a clear suggestion for identifying cross-sectional heterogeneity: Firms with low surtax margins are a priori less likely to face differentially costly external finance. Indeed, in many cases these firms turned to external markets to raise funds in order to increase dividend payments, thereby reducing surtax payments. As we 
show in the Appendix, the maximum SUP margin can provide a measure of the shadow cost of external finance.

In this reduced-form approach, firms in higher naximum SUP margins (those with higher costs of external finance) will have greater sensitivity of investment to shifts in internal funds, holding constant differences in cash flow and investment opportunities. We investigate this proposition in Table 11, which reports results for two regressions with investment relative to fixed capital as the dependent variable (i.e., the percentage change in fixed capital from 1934 to 1937). ${ }^{18}$ In both regressions the market-to-book value ratio (Q) in 1936 is included as a proxy for investment opportunities. ${ }^{19}$ The $(\mathrm{CF} / \mathrm{K})$ term is defined as cash flow from 1934 to 1937 , divided by fixed capital in 1934. The first regression constrains the intercept and the cash-flow responsiveness of investment to be identical across different types of firms, while the second regression allows the intercept and cash-flow coefficient to vary across firm types. We report regressions that constrain the $Q$ coefficients to be identical across types, as well as regressions that do not.

Our results provide broad support for the simple approach discussed above. In the aggregated regression, both $Q$ and cash flow enter positively and statistically significant at the 1-percent level. The coefficient on $Q$ is large relative to previous estimates, indicating lower adjustment costs than those implied in the estimates by Summers (1981); Salinger and Summers (1983); Fazzari, Hubbard, and Petersen (1988); and others. The results allowing for surtax-margin heterogeneity reveal that the sensitivity of investment to internal funds is concentrated in the Type $C$ firms. In all the regressions, Type $A$ and $B$ firms exhibit no responsiveness of investment to changes in cash flow after taking account of investment 
opportunities measured by $Q$, but for Type $C$ firms the coefficient is large $(0.27)$ and statistically significant. ${ }^{20}$ Allowing for heterogeneity in effects of internal funds on investment raises the $R$-squared of the regression from 0.11 to 0.21 . These results are not attributable to greater measurement error in $Q$ for Type $C$ firms (and hence greater marginal information contributed by cash flow). If measurement error in $Q$ were relatively large for Type C firms, then one would expect the coefficients on $Q$ for Type $C$ firms to be relatively small. However, the opposite is the case. In regressions that allow the coefficient on $Q$ to vary by type, Type B and C firms have larger estimated Q coefficients than Type A firms.

In the above analysis, we used the peak $Q$ value (at the end of 1936) to minimize the chance of finding a marginal contribution from cash flow. Still, one could argue that it is inappropriate to include in the dependent variable investment for years prior to the measurement of $Q$. Furthermore, cash flow measured after the date $Q$ is measured might contain marginal information about future profitability, which coincidentally might have had greater relevance for type $C$ firms. We confront these potential problems by estimating (2) using investment data for 1936 alone, and by using definitions of cash flow inclusive and exclusive of contemporaneous data. Results from five such regressions are reported in Table 12, using the change in fixed capital from the end of 1935 to the end of 1936 as the dependent variable, and using as regressors $Q$ in 1935 and, alternatively, the sum of cash flow in 1935 and 1936 , or cash flow in 1935 . The results are quite sinvilar to those in Table 11 , although the coefficient on $Q$ in the single-year investment regression is predictably smaller. As before, only Type $C$ firms show significant responsiveness to internal finance (inclusive or exclusive of current cash flow). The increase in R-squared due to 
disaggregation is even more pronounced than before. Once again, it is not appropriate to interpret our findings as the result of differential measurement error of $Q$ since the $Q$ coefficients are larger for Type $C$ firms.

We also tested for additional effects of cash flow on changes in working capital. Firms with high costs of external finance and excess sensitivity of investment to changes in cash flow will have an incentive to "self-insure" against variation in internal funds by accumulating working capital during periods when cash flow is high and decumulating working capital during periods when cash flow is low. ${ }^{21}$ If working capital serves as a buffer to reduce the variation in fixed investment caused by variation in cash flow, then for Type C firms, working capital investment will respond even more to changes in cash flow than fixed capital investment.

To test this, we estimate a model similar to (2), but with the change in working capital as the dependent variable (normalized, as throughout, by fixed capital). In this regression there is no clear null hypothesis for the coefficient on cash flow (as there is in the Q-theory model for fixed investment), but we find the heterogeneity of our reduced-form coefficients on cash flow across the various types to be suggestive. Our results are reported in Table 13. The coefficient on cash flow is much larger for Type $C$ firms than for others, and it is nearly double the comparable Type $\mathrm{C}$ firm coefficient in Table 11. These results are consistent with the view that firms with high external finance costs rely on working capital as a buffer to reduce the effects of cash flow variation on fixed investment.

To summarize, we estimated versions of a neoclassical investment model controlling for firms' investment opportunities using Tobin's $Q$. The inclusion of proxies for internal funds 
could be rejected for firms which avoided high margins of the surtax on undistributed profits by increasing dividends. For profitable firms with low dividend payout and high surtax margins, we could not reject a reduced-form effect on investment spending of internal funds, holding constant investment opportunities. These results are robust to changes in the definition of internal funds -- in particular the use of only lagged internal funds -- in the regressions, and are not explicable by appeal to measurement error in Tobin's Q. Finally, high-surtax-margin firms show a much higher propensity to adjust working capital in response to changes in internal funds, in a manner consistent with a buffer-stock view of the function of working capital.

\section{MEASURED CAPITAL-MARKET FRICTIONS AND GROWING FIRMS}

Using firms' marginal surtax rates we showed above that a simple formulation of the effects on investment of financing costs and investment opportunities (through the $Q$ model) supports the economic and statistical significance of both. Consistent with models of capitalmarket frictions, the investment of firms paying the highest rates of surtax was sensitive to shifts in both firms' opportunities and internal funds.

These results would have come as no surprise to critics of the surtax, who argued that young, growing firms with high costs of external finance bore the brunt of the tax. These critics (see e.g., Merwyn, 1942; and Butters and Lintner, 1945), many of whom pushed for repeal of the surtax from its inception, were particularly concerned about the surtax's effect on growing industries. Table 14 reports the numbers of firms of Types $A, B$, and $C$ for each of the industries enumerated in the Survey of Listed Corporations, our data source. 
Also reported are (i) the fraction of firms in each industry that are in Type $C$ and (ii) the growth rate of the industry's fixed capital stock (measured in constant dollars) over the period from 1937 to 1948 . We calculated the latter to examine whether the industries with significant representation of Type C firms in fact were (ex post) the "growth industries" of the period.

It is not possible to make precise statements about the correlation of the importance of Type $\mathrm{C}$ firms and industry growth because the industry classification reported in the data does not match exactly the Census S.I.C. definition of industries. Nonetheless, some patterns are noteworthy. The fixed capital stocks of the four industries with at least 50 percent of sample firms in Type C (agricultural machinery, aircraft, engines and turbines, and tires) grew significantly faster than the average for the manufacturing sector. ${ }^{22}$ It is also possible that other Type $C$ firms were in relatively fast-growing segments of their respective industries. To summarize, the characterization of Type $C$ firms (the investment behavior of which is affected by financial constraints) as being disproportionately concentrated in growing industries appears to be accurate, providing support for concerns of contemporary chroniclers.

\section{VII, CONCLUSION}

Recent theoretical models have linked firms' internal funds and investment spending in environments where extemal funds are more costly than internal funds. An important impediment to convincing tests of these models has been the identification of firm-level differences in the costs of extemal finance. The Surtax on Undistributed Profits in the 1930 s 
offers a rare opportunity to measure the shadow price differential between internal and extemal finance, and thereby, measure the importance of external finance constraints associated with a "financing hierarchy" in determining investment behavior. In addition, firm-level analysis of investment and financing costs for the 1930s provides complementary evidence to Bernanke's (1983) time-series analysis, and can help to verify whether recovery from the Depression was likely to have been delayed by high costs of financing investment.

Our results make some progress on both fronts. Nearly one-fourth of publicly traded manufacturers in our sample had maximum SUP margins of 22 or 27 percent. The cash-flow sensitivity of fixed investment by these firms alone accounts for the overall sensitivity of investment to cash flow in our data, after controlling for investment opportunities. Many firms with high surtax margins were concentrated in the growing industries of the day. The sensitivity of capital spending to internal funds for high-surtax-margin firms appears to reflect information-related capital-market frictions as opposed to the waste of corporate cash flows by entrenched managers.

Our results also contain implications for fiscal and monetary policy. Our finding that internal finance can have an important allocative role in investment implies that the social costs of taxing firms' profits may include allocative distortions from reductions in intemal finance for some firms. These costs are borne disproportionately by young, growing firms which suffer problems of asymmetric information. The high costs of external finance and the existence of a financing cost hierarchy also lend credence to viewing changes in the credit supply of intermediaries specializing in monitoring firms described above as an important channel of monetary policy. ${ }^{23}$ 


\section{NOTES}

1. See for example Fazzari, Hubbard, and Petersen (1988) and Hoshi, Kashyap, and Scharfstein (1991).

2. Romer and Romer (1990) and Miron (1991) have stressed the value of historical policy experiments in models of interest to macroeconomists.

3. Indeed opponents of the surtax (which was only effective for two years) argued that it discriminated against firms with limited (or costly) access to centralized securities markets (see Butters and Lintner, 1945; and Kendrick, 1937). Contemporary chroniclers emphasized the effect of bank failures and reduced credit availability from banks in increasing the shadow price of external finance for many firms in the 1930s.

4. Calomiris and Hubbard (1989) report similar results for the pre-Federal Reserve period of U.S. history. Temin (1989) uses panel data for investment to challenge Bernanke's view that costs of credit were unusually high during the 1930s. Temin argues that if Bernanke's channel were important industries with low concentration ratios (which Temin identifies as more vulnerable to increases in the cost of credit intermediation), should have invested relatively less in the 1930 s than at other times. Temin finds no evidence to support this prediction, and therefore, dismisses the credit-cost explanation of the Great Depression's unusual persistence. Clearly, it would be preferable to measure investment response at the firm level using a direct measure of the shadow cost of external finance, rather than rely on comparisons across industries using the dubious proxy of industrial concentration. Indeed, as we show below, firm size (which motivates Temin's use of industry concentration) is a very noisy indicator of external finance costs.

5. Another possible contributor to the intellectual current in support of the surtax was the "liquidationist" school of thought, discussed in DeLong (1991). According to this school, depressions were necessary times of upheaval in which reallocations of capital from low-productivity to highproductivity uses occurred. The "discipline" of external finance might have been valued as a means to hasten such a transformation.

\section{See also Ramakrishnan and Thakor (1984).}

7. For the sample of publicly traded firms we discuss in succeeding sections, only one in four firms issued bonds in 1936. Given the low brokerage costs of bond issues and the tax reduction benefits of debt, particularly in the presence of the surtax, it seems reasonable to interpet this low participation rate as evidence that many firms simply did not qualify for the bond market. Other evidence supports this conclusion. Ten percent of the firms in our sample accounted for 90 percent of firms' bond issues. Participation rates in the bond market for large firms (those with assets greater than $\$ 100$ million) were nearly triple those for other firms. The mean size of bond issuers was more than triple the mean size of non-issuers. Finally, very few firms were "on the bond margin" in 1936. Only 11 firms in our sample of 273 increased outstanding bonds in 1936 or 1937, while 7 firms showed a substantial decrease. Haven $(1940$, p. 7$)$ argues that marketing restrictions on low-grade bonds introduced by the Banking Act of 1935 effectively restricted bond issues by small corporations in the mid-1930s. 
8. As a technical matter, firms could circumvent payment of additional cash dividends by distributing certain types of stock dividends (see Rolbein, 1939). Firms, however, had to prove that such "dividends" increased the effective claims of shareholders.

9. This may not be true for periods outside our sample which saw lower levels of gross investment. Errors due to depreciation likely were reduced in importance by the high investment levels of 1935 and 1936.

10. An added advantage to using fewer groupings is the reductions in the possibility of measurement error of type. Such errors might result from attempts by firms to disguise or reduce measured profits to reduce the burden of the surtax. For example, in closely held firms, managers would substitute direct compensation for dividends. Firms would also have incentives to increase advertising and maintenance expenses if they thought the tax was temporary. Also, the expensing of some forms of capital might have led some high-margin firms to accelerate some forms of capital investment. This latter effect seems to have been important in explaining investment in oil drilling equipment, which was expensed (see Hubbard and Reiss, 1988). Thus so long as firms faced upward sloping cost of fund schedules, these various influences could lead us to underestimate some firms' external finance costs. By having few categories of firms we minimize the bias that could come from such possible mismeasurement. In fact, our regression results indicate substantial differences in behavior for Type $\mathrm{C}$ firms relative to Type $\mathrm{A}$ and $\mathrm{B}$ firms. Thus, we believe that few of the highest-margin firms avoid detection in our sample.

11. The large standard deviation for Type $C$ asset size is attributable to 7 large firms at the 22 percent margin whose mean asset size in 1936 was $\$ 211$ million.

12. The measured increases for all types in the ratio of net operating profits to sales is possibly surprising given the incentives for firms to increase expenses to avoid the surtax (i.e., move forward plans for advertising, and substitute executive compensation for owner-managers' capital gains). We take this as an encouraging sign that errors in measurement of surtax margins as a consequence of "expense padding" are likely to be small for most of our sample.

13. The values in Table 8 likely understate values for Tobin's $Q$ in the economy. In particular, the average and median values reported in Table 8 are likely to be less than the true average and median values of Tobin's $Q$ because of the difference between replacement cost and book value for firms in 1936. As Kuznets (1961, p. 480) shows, the price index for producer durables was 15 percent lower in 1936 than in 1929, owing to the great deflation of 1929-1933. Since most capital was purchased prior to the deflation, book value was far in excess of replacement cost.

14. The adverse selection model of Myers and Majluf (1984), for example, does not predict whether the average ratio of market to book value for pooled asymmetric-information firms will be above or below one.

15. Mean ratios of bond debt to assets are essentially the same across types $(0.03$ for Type $A$ and $B$ firms, and 0.04 for Type $C$ firms). Thus differences in debt-equity ratios are mainly attributable to short-term debt. 
16. Townsend (1979), Diamond (1984), Gale and Hellwig (1985), Williamson (1986), and Lacker (1990) have argued for the importance of ex post asymmetric information. Townsend and GaleHellwig show that when lenders find it costly to verify firm profits debt contracts will be useful as a means of limiting the states in which verification is required. Diamond and Williamson show that intermediated debt further can reduce costs associated with ex post bankruptcy penalties and state verification. Lacker shows that collateralized debt is a useful means of creating incentives for accurate reporting of outcomes in environments where realizations cannot be verified by lenders. Collateral provides a credible penalty on borrowers who fail to meet their promises because borrowers value the collateral good more than lenders. These arguments predict that firms for which ex post information asymmetry is relevant should rely more on debt. Moreover, in models of ex ante asymmetric information (for example, the adverse selection models of Myers and Majluf, 1984, and DeMeza and Webb, 1987), debt is the optimal contract when firms differ unobservably in mean returns to firm investments. Firms with higher expected project returns prefer debt because it offers them higher expected profits, and low-returns firms are obliged to mimick the preferences of highreturns firms. Some combination of ex ante and ex post asymmetric information that motivate higher debt ratios (along with bankruptcy costs that limit optimal debt ratios), may help to explain the crosssectional differences in the reliance on debt.

17. An alternative approach to such tests is to estimate directly the Euler equation for capital accumulation, as in Gilchrist (1990), Himmelberg (1990), Whited (1990), and Hubbard and Kashyap (1990). We did not pursue this strategy, owing to difficulties in constructing a balanced panel with data on firm financial and real variables over the 1935-1938 period.

18. One can also argue that the intercept terms should be lower for high-surtax-margin firms -- that is, that higher financing costs not captured by cash flow and $Q$ should reduce investment for any given levels of cash flow and $Q$. Indeed, we find that the intercept for net investment is zero for Type A and Type B firms, but substantially negative for Type C firms.

19. We collected market-value data for firms in 1935 and 1936 only. Data for earlier years were much more difficult to find.

20. As we noted before, the only intercept term that is significantly different from zero is that for Type $\mathrm{C}$ firms, which is strongly negative $(-0.16)$.

21. Fazzari and Petersen (1990) have argued that working capital plays an important role in allowing firms to avoid costs of adjustment in fixed capital investment.

22. This does not imply that firms in Types A or B were only in slow-growing industries. The capital stock of the petroleum industry grew rapidly over the period, and only relatively large, mature oil firms were in the sample.

23. We have argued that the SUP offers a way to identify the incidence of "financing constraints" across firms. Firm heterogeneity in responses of investment, employment, or production to changes in monetary policy would provide another example (see Gertler and Hubbard, 1988; and Gerler and Gilchrist, 1991). 


\section{APPENDIX \\ APPROXIMATING THE SHADOW COST OF FINANCE USING THE SURTAX}

It is possible to obtain an estimate of the cost differential between external and internal finance using estimates of the maximum surtax rate paid, and other data. Consider the case of an all-equityfinanced firm, in which dividend payments do not affect the required rate of return on the firm's equity (the "tax capitalization" model of dividends and investment formulated by King, 1977; Auerbach, 1979; and Bradford, 1981). Define the following variables:

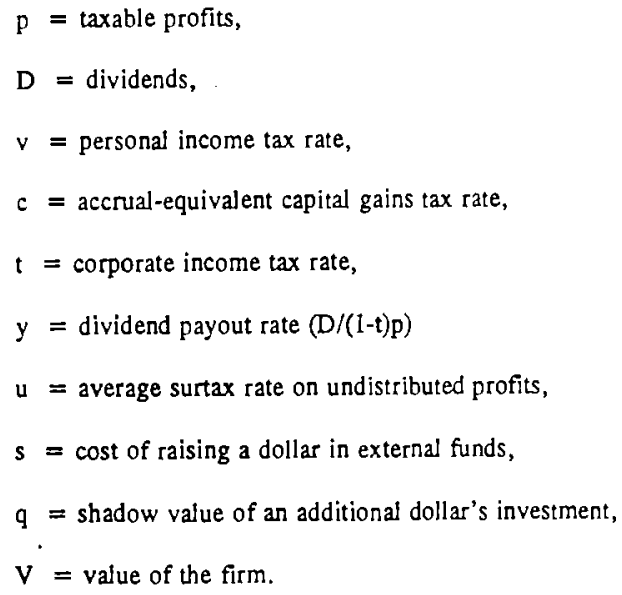

Note that since after-tax profits are given by

$$
(1-t) p-u(y)[(1-t) p-D],
$$

an increase in dividends $(\mathrm{dD})$ reduces the surtax liability of the firm by

$$
\left[u(y)+(y-1) u^{\prime}(y)\right] d D .
$$

Consider an experiment in which a firm increases dividend payments by one dollar, while raising an additional dollar of equity. The effect on firm value is given by: 


$$
(1-v)+q(I-c)\left[u(y)+u^{\prime}(y)(y-1)\right]-(1+s) .
$$

The first term reflects the value to shareholders of an additional dollar of dividends. The second term represents the value of reinvested savings from reduced surtax liability. The cost of an additional dollar of external finance is $(1+s)$. Note that if $u=s=0$, a firm would issue new shares only if $q>$ 1.

For our purposes, an interesting benchmark is the responsiveness to the surtax on undistributed profits of firms initially paying near-zero dividends, for which $y$ is near zero,

$u=0.21$, and $u^{\prime}=-0.13$. If the dividend payout ratio does not change ex post, it must be the case that:

$$
(0.34) q(1-c)-v<s .
$$

Poterba's (1987) estimates of $c$ and $v$ for 1935 (just prior to the imposition of the surtax) are 0.06 and 0.24 , respectively. Assuming a lower bound for $q$ of $(1+s)$ implies a cost premium for external finance of at least 12 percent. If $q=1.5$, the implied cost differential is at least 24 percent.

Assuming $q=1.5$ seems conservative. As we have argued, Type-C firms were often young, high-growth firms. Moreover, estimates of market-to-book value reported in Table 8 show an average for Type- $C$ firms of 1.3 and a median of 0.98 . Replacement cost for producer durables was much lower than book value for these firms, whose equipment would have been purchased prior to the great deflation of 1929-1933. Kuznets (1961, p. 480) estimates that the cost of producer durables was 15 percent lower in 1936 than it was in 1929. Adjusting for this decline would raise the estimated market evaluation of $q$ for Type- $C$ firms to a median of 1.16 and a mean of 1.5 , assuming all capital was purchased in 1929. Finally, in the presence of asymmetric information, as Myers and Majluf (1984) argue, the true $q$, as known to insiders, could be substantially greater than the market estimate. Thus a $q$ value of 1.5 , and an implied value for $s$ of 24 percent for zero-dividend firms, seems conservative. 
Our approach to estimating $s$ is conservative for two additional reasons. First, we do not allow any direct effect from dividend policy to firm valuation (as models based on dividend valuation for purposes of signalling or managerial discipline would imply). Second, for firms paying zero dividends, our estimates are a lower bound because those firms are at a corner solution. 


\section{REFERENCES}

Auerbach, Alan J. 1979. "Wealth Maximization and the Cost of Capital." Quarterly Journal of Economics 93 (August), 433-446.

Benveniste, Lawrence M., and Spindt, Paul A. 1989. "How Investment Bankers Determine the Price and Allocation of New Issues." Journal of Financial Economics 24 (October), 343-61.

Berle, Adolph A., and Means, Gardiner. 1932. The Modern Corporation and Private Property. New York: Columbia University Press.

Bernanke, Ben, and Gertler, Mark, 1990. "Financial Fragility and Economic Performance." Quarterly Journal of Economics 104 (February), 87-104.

Bernanke, Ben. 1983. "Non-Monetary Effects of the Financial Crisis in the Propagation of the Great Depression." American Economic Review 73 (June), 257-276.

Blakey, Roy G. and Blakey, Gladys C. 1936. "The Revenue Act of 1936." American Economic Review 26 (September), 466-482

Buehler, Alfred G. 1937. The Undistributed Profits Tax. New York: McGraw Hill.

Butters, J. Keith, and Lintner, John V. 1945. The Effect of Federal Taxes on Growing Enterprises. Boston: Division of Research, Graduate School of Business Administration, Harvard University.

Calomiris, Charles W. 1992. "The Costs of Rejecting Universal Banking: American Finance in the German Mirror, 1870-1914. Mimeograph, University of Illinois.

Calomiris, Charles W., and Hubbard, R. Glenn. 1990. "Firm Heterogeneity, Internal Finance, and Credit Rationing." Economic Journal 100 (March), 90-104.

Calomiris, Charles W., and Hubbard, R. Glenn. 1989. "Price Flexibility, Credit Availability, and Economic Fluctuations." Quarterly Journal of Economics 103 (August), 429-452.

De Long, J. Bradford. 1991. "'Liquidation' Cycles: Old-Fashioned Real Business Cycle Theory and the Great Depression." Mimeograph, Harvard University.

De Meza, David, and Webb, David C. 1987. "Too Much Investment: A Problem of Asymmetric Information." Quarterly Journal of Economics (May), 281-92

Diamond, Douglas W. 1984. "Financial Intermediation and Delegated Monitoring." Review of Economic Studies (July), 393-414

Dobrovolsky, S.P. 1951. Corporate Income Retention, 1915-43. New York: National Bureau of Economic Research.

Easterbrook, Frank H. 1984. "Two Agency-Cost Explanations of Dividends." American Economic Review 74 (June), 650-659. 
Fazzari, Steven M., Hubbard, R. Glenn, and Petersen, Bruce C. 1988. "Financing Constraints and Corporate Investment." Brookings Papers on Economic Activity (no. 1), 141-195.

Fazzari, Stephen M., and Petersen, Bruce C. 1990. "Investment Smoothing with Working Capital: New Evidence on the Impact of Financial Constraints." Mimeograph, Federal Reserve Bank of Chicago.

Gale, Douglas, and Hellwig, Martin. 1985. "Incentive-Compatible Debt Contracts: The One-Period Problem." Review of Economic Studies (October), 647-63

Gertler, Mark and Gilchrist, Simon. 1991. "Monetary Policy, Business Cycles, and the Behavior of Small Manufacturing Firms." Mimeograph, New York University.

Gertler, Mark, and Hubbard, R. Glenn. 1989. "Financial Factors in Business Fluctuations." In Federal Reserve Bank of Kansas City, Financial Market Volatility -- Causes, Consequences, and Policy Responses.

Gertler, Mark. 1988. "Financial Structure and Aggregate Economic Activity: An Overview." Journal of Money, Credit and Banking 20 (August, Part 2), 559-588.

Gilchrist, Simon. 1990. "An Empirical Analysis of Corporate Investment and Financing Hierarchies Using Firm Level Panel Data." Mimeograph, Federal Reserve Board.

Gilchrist, Simon, and Himmelberg, Charles P. 1991. "Estimates of a Structural Investment Model Using Panel Data: A Vector Autoregression Approach." Mimeograph, New York University.

Guthman, Harry G. 1940. "The Effect of the Undistributed Profits Tax Upon the Distribution of Corporate Earnings: A Note." Econometrica 8 (October), 354-356.

Hanka, Gordon. 1992. "Does Wall Street Want to Harm Their Neighbors and Employees?" Ph.D. Dissertation, University of Chicago.

Harris, Milton, and Raviy, Artur. 1990. "Capital Structure and the Informational Role of Debt." Journal of Finance (January), $32 !-49$.

Haven, T. Kenneth. 1940. "Investment Banking Under the Securities and Exchange Commission." Michigan Business Studies 9 (Number 3), 1-157.

Hayashi, Fumio. 1982. "Tobin's Marginal q and Average q: A Neoclassical Interpretation." Econometrica 50 (January), 213-224.

Hazelett, C. William. 1936. Incentive Taxation. New York: Dutton.

Himmelberg, Charles P. 1990. "A Dynamic Analysis of Dividend and Investment Behavior Under Borrowing Constraints." Mimeograph, New York University. 
Hoshi, Takeo, Kashyap, Anil, and Scharfstein, David. 1991. "Corporate Structure, Liquidity, and Investment: Evidence from Japanese Industrial Groups." Quarterly Journal of Economics 105 (February), 33-60.

Hubbard, R. Glenn, and Reiss, Peter C. 1988. "Corporate Payouts and the Tax Price of Corporate Retentions: Evidence from the Undistributed Profits Tax of 1936-1938." Mimeograph, Columbia University.

Hubbard, R. Glenn, and Kashyap, Anil. 1991. "Internal Net Worth and the Investment Process: An Application to U.S. Agriculture." Journal of Political Economy, forthcoming.

Jaffee, Dwight, and Russell, Thomas. 1976. "Imperfect Information, Uncertainty, and Credit Rationing." Quarterly Journal of Economics 50 (November), 651-666.

Jensen, Michael C. 1986. "Agency Costs of Free Cash Flow, Corporate Finance, and Takeovers." American Economic Review 76 (May), 323-330.

Jog, Vijay, and Schaller, Huntley. 1992. "Finance Constraints and Asset Pricing: Evidence on Mean Reversion." Mimeograph, Carleton University.

Kendrick, M. Slade. 1937. The Undistributed Profits Tax. Washington, D.C.: Brookings Institution.

King, Mervyn A. 1977. Public Policy and the Corporation. London: Chapman and Hall.

Korajczyk, Robert A., Lucas, Deborah, and McDonald, Robert L. 1990. "Understanding Stock Price Behavior around the Time of Equity Issues." In R. Glenn Hubbard, Asymmetric Information. Corporate Finance, and Investment, 257-78. Chicago: University of Chicago.

Kuznets, Simon. 1961. Capital in the American Economy. Princeton: Princeton University Press.

Lent, George E. 1948. The Impact of the Undistributed Profits Tax, 1936-1937. New York: Columbia University Press.

McIntyre, Francis. 1939. "The Effect of the Undistributed Profits Tax on the Distribution of Corporate Earnings - A Statistical Appraisal." Econometrica 7 (October): 336-348.

Mendelson, Morris. "Underwriting Compensation." In Irwin Friend, et al., eds., Investment Banking and the New Issues Market. New York: The World Publishing Company.

Merwin, Charles L., Jr. 1942. Financing Small Corporations. New York: National Bureau of Economic Research.

Miron, Jeffrey A. 1991. "The Role of Economic History in Economic Research: A Review Essay." Journal of Monetary Economics 27 (April), 293-300. 
Myers, Stewart C., and Majluf, Nicholas S. 1984. "Corporate Financing Decision When Firms Have Investment Information That Investors Do Not." Inurnal of Financial Economics 13 (June), 187-220.

Poterba, James M. 1987. "Tax Policy and Corporate Saving." Brookings Paners on Economic Activity (no. 2), 455-503.

Poterba, James M., and Summers, Lawrence H. 1985. "The Economic Effects of Dividend Taxation." In E.I. Altman and M.G. Subrahmanyan, eds., Recent Advances in Corporate Finance. Homewood, Illinois: Richard D. Irwin.

Ramakrishnan, Ram T.S., and Thakor, Anjan V. 1984. "Information Reliability and a Theory of Financial Intermediation." Review of Economic Studies (July), 415-32.

Rolbein, David L. 1939. "Non-Cash Dividends and Stock Rights as Methods for Avoidance of the Undistributed Profits Tax." Journal of Business 12 (July), 221-264.

Romer, Christina and Romer, David. 1990. "Does Monetary Policy Matter?: A New Test in the Spirit of Friedman and Schwartz," in O.J. Blanchard and S. Fischer, eds., NBER Macroeconomics Annual. 1990. Cambridge: MIT Press.

Salinger, Michael A., and Summers, Lawrence H. 1983. "Tax Reform and Corporate Investment: A Microeconomic Simulation Study." In Martin Feldstein, Behavioral Simulation Methods in Tax Policy Analysis. Chicago: University of Chicago Press, 247-81.

Securities and Exchange Commission. 1941a. Cost of Flotation for Registered Securities, 19381939. Washington, D.C.: The Commission.

Securities and Exchange Commission. 1941b. "Statistical Release No. 572." Washington, D.C.: The Commission.

Stiglitz, Joseph E., and Weiss, Andrew. 1981. "Credit Rationing in Markets with Imperfect Information." American Economic Review 71 (June), 393-410.

Summers, Lawerence H. 1981. "Taxation and Corporate Investment: A q-Theory Approach." Brookings Papers on Economic Activity, I, 67-127.

Temin, Peter. 1989. Lessons from the Great Depression. Cambridge: MITT Press.

Thorp, Willard L., and George, Edwin B. 1937. "An Appraisal of the Undistributed Profits Tax." Dun's Review (September), 5-36.

Townsend, Robert. 1979. "Optimal Contracts and Competitive Markets with Costly State Verifications." Journal of Economic Theory (October), 265-93.

Tugwell, Rexford G. 1933. The Industrial Discipline and the Governmental Ans. New York: Columbia University Press. 
Whited, Toni M. 1990. "Debt, Liquidity Constraints, and Corporate Investment: Evidence from Panel Data," Mimeograph, Boston College.

Williamson, Stephen D. 1986. "Costly Monitoring, Financial Intermediation, and Equilibrium Credit Rationing." Journal of Monetary Economics (September), 159-80 
Table 1

Retained Earoings as a Percentage of After-Tax Profits for Corporations with Positive Income, 1931-40

(Asset Size Classes in Thousunss of Dollarv)

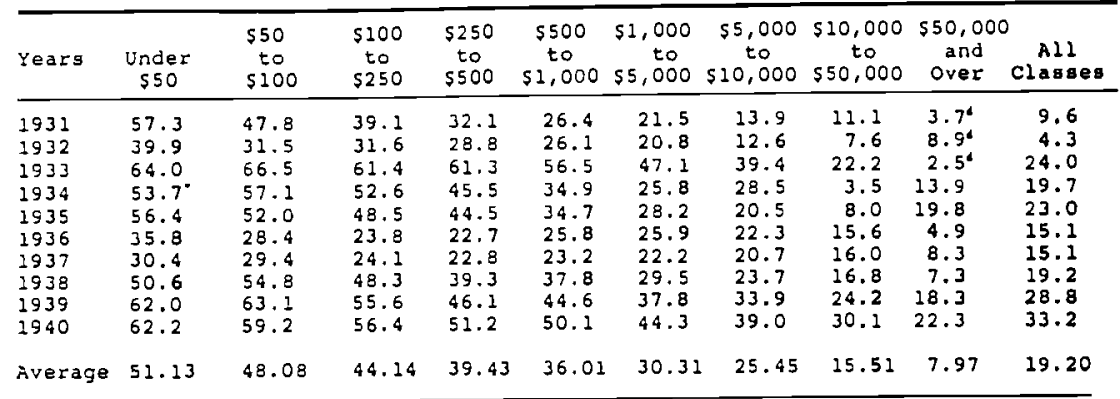

SOURCE: Bullers and Lin!ner (1945), p, 66, compuled from Starissics of Income.

indicates an excest of dividende over nel profis after uxes.

This liem represents nonfinane inl corporalions only, because of the abnormal dividends paid by finencis corporations of this size in 1934 . 
Table 2

Corporations subject to Surtax on Undistributed Profits, 1937 (Classified by Highest Surtax Paid)

\begin{tabular}{|c|c|c|c|c|c|c|c|}
\hline $\begin{array}{l}\text { Net Income } \\
\text { class } \\
(000 \mathrm{~B})\end{array}$ & $\begin{array}{l}\text { Returns } \\
\text { With Net } \\
\text { Income }\end{array}$ & $\begin{array}{c}\text { No } \\
\text { Surtax } \\
(8)\end{array}$ & $\begin{array}{c}78 \\
\text { Rate } \\
(8)\end{array}$ & $\begin{array}{l}128 \\
\text { Rate } \\
(8)\end{array}$ & $\begin{array}{l}178 \\
\text { Rate } \\
(8)\end{array}$ & $\begin{array}{l}22 \% \\
\text { Rate } \\
(8)\end{array}$ & $\begin{array}{l}27 \% \\
\text { Rate } \\
(8)\end{array}$ \\
\hline $\begin{array}{l}<55 \\
5-10 \\
10-15 \\
15-20 \\
20-25 \\
25-50 \\
50-100 \\
100-250 \\
250-500 \\
500-1000 \\
1000-5000 \\
>5000\end{array}$ & $\begin{array}{r}119,805 \\
18,611 \\
9,150 \\
5,697 \\
3,879 \\
9,282 \\
6,046 \\
4,620 \\
1,819 \\
1,071 \\
974 \\
240\end{array}$ & $\begin{array}{l}19.28 \\
34.7 \\
38.0 \\
40.0 \\
39.8 \\
40.5 \\
39.8 \\
38.8 \\
38.3 \\
36.4 \\
42.2 \\
43.3\end{array}$ & $\begin{array}{l}80.88 \\
39.4 \\
32.4 \\
27.4 \\
24.1 \\
18.0 \\
13.7 \\
13.0 \\
13.2 \\
13.8 \\
15.1 \\
15.8\end{array}$ & $\begin{array}{r}0.8 \\
8.9 \\
5.6 \\
7.5 \\
7.7 \\
8.7 \\
9.9 \\
9.6 \\
9.2 \\
13.8 \\
11.8 \\
17.5\end{array}$ & $\begin{array}{r}0.8 \\
10.4 \\
6.1 \\
8.3 \\
11.2 \\
13.1 \\
15.7 \\
15.8 \\
16.7 \\
17.6 \\
16.5 \\
16.7\end{array}$ & $\begin{array}{l}0.8 \\
6.6 \\
7.4 \\
4.7 \\
5.4 \\
8.6 \\
9.9 \\
11.8 \\
13.0 \\
10.2 \\
9.4 \\
5.0\end{array}$ & $\begin{array}{l}08 \\
0 \\
10.7 \\
12.1 \\
11.8 \\
11.1 \\
10.9 \\
11.1 \\
9.6 \\
8.1 \\
4.9 \\
1.7\end{array}$ \\
\hline
\end{tabular}

SOURCE: Figures are derived from Statistics of income for 1937. 
Table 3

Cost of Flotation for Common stock Issues Effectively Registored for sale to the Public by Asset Size of Issuer, 1938-1941

\begin{tabular}{|c|c|c|c|c|c|c|c|c|}
\hline \multirow[b]{2}{*}{$\begin{array}{l}\text { size of lssuer } \\
\text { (in millions) }\end{array}$} & \multicolumn{2}{|c|}{1938} & \multicolumn{2}{|c|}{1938} & \multicolumn{2}{|c|}{1960} & \multicolumn{2}{|c|}{1961} \\
\hline & $\begin{array}{c}\text { No. } \\
\text { issues }\end{array}$ & $\begin{array}{l}\text { Cost as a } \\
\text { Percentage } \\
\text { of Amount }\end{array}$ & $\begin{array}{c}\text { No. } \\
\text { Issues }\end{array}$ & $\begin{array}{l}\text { Cost us a } \\
\text { Percentage } \\
\text { of Amount }\end{array}$ & $\begin{array}{l}\text { Ho. } \\
\text { I ssues }\end{array}$ & $\begin{array}{l}\text { Cost as : } \\
\text { Percentage } \\
\text { of Amount }\end{array}$ & $\begin{array}{c}\text { No. } \\
\text { issues }\end{array}$ & $\begin{array}{l}\text { Cost as: } \\
\text { Percentegs } \\
\text { of Amount }\end{array}$ \\
\hline \multicolumn{9}{|l|}{$\begin{array}{l}\text { Underwibien } \\
\text { Issues }\end{array}$} \\
\hline $\begin{array}{l}\text { Under } \$ \\
\$ 1-\$ 5 \\
\$ 5-310 \\
\$ 10-\$ 50 \\
\$ 50-\$ 100 \\
\$ 100-\$ 200 \\
\text { Over } \$ 200\end{array}$ & $\begin{array}{l}9 \\
5 \\
2 \\
\cdots \\
\cdots \\
\cdots\end{array}$ & $\begin{array}{c}27.37 \\
20.0 \\
19.2 \\
. . \\
. . \\
. .\end{array}$ & $\begin{array}{l}13 \\
0 \\
3 \\
\cdots \\
\cdots \\
\cdots\end{array}$ & $\begin{array}{c}22.97 \\
19.5 \\
11.4 \\
. . \\
. \\
\ldots \\
.\end{array}$ & $\begin{array}{c}10 \\
19 \\
3 \\
6 \\
1 \\
1 \\
\cdots\end{array}$ & $\begin{array}{c}22.87 \\
15.9 \\
12.9 \\
10.4 \\
0.1 \\
8.3 \\
. .\end{array}$ & $\begin{array}{r}5 \\
11 \\
3 \\
3 \\
\because \\
\therefore \\
\cdots\end{array}$ & $\begin{array}{c}20.67 \\
19.9 \\
12.5 \\
10.2 \\
\ldots \\
\ldots\end{array}$ \\
\hline \multicolumn{9}{|l|}{$\begin{array}{l}\text { Wonundertiritten } \\
\text { Issues }\end{array}$} \\
\hline $\begin{array}{l}\text { Under } \$ 1 \\
\$ 1-\$ 5 \\
\$ 5-\$ 10 \\
\$ 10-\$ 50 \\
\$ 50-\$ 100 \\
\$ 100-\$ 200 \\
\text { over } \$ 200\end{array}$ & $\begin{array}{l}46 \\
6 \\
2 \\
\cdots \\
\cdots \\
\cdots\end{array}$ & $\begin{array}{c}21.7 x \\
20.9 \\
14.8 \\
. \\
. \\
\therefore \\
.\end{array}$ & $\begin{array}{r}36 \\
10 \\
2 \\
1 \\
\therefore \\
\therefore \\
\therefore\end{array}$ & $\begin{array}{c}26.1 x \\
20.3 \\
10.9 \\
6.8 \\
\ldots \\
\ldots\end{array}$ & $\begin{array}{l}31 \\
3 \\
2 \\
i \\
\cdots \\
\cdots\end{array}$ & $\begin{array}{c}26.67 \\
16.5 \\
16.4 \\
2.2 \\
\because \\
\therefore\end{array}$ & $\begin{array}{r}7 \\
2 \\
1 \\
\because \\
1 \\
\cdots\end{array}$ & $\begin{array}{c}19.1 x \\
23.6 \\
16.8 \\
4.6 \\
\therefore\end{array}$ \\
\hline
\end{tabular}

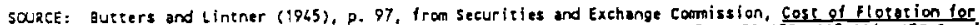

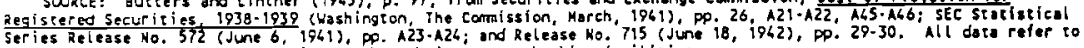
issues proposed for sale by the issuer through investment banking facillities. 
Table 4

Dividends Relative to After-Tax Profits, 1935 and 1936

\begin{tabular}{lcccc}
\hline & Type A & Type B & TYpe C & A11 Firms \\
\hline 1935 & & & & \\
Mean & 1.796 & 0.516 & 0.273 & 1.054 \\
Median & 0.702 & 0.512 & 0.042 & 0.520 \\
Standard deviation & 9.932 & 0.461 & 0.399 & 210 \\
Number of firms & 124 & 78 & 64 & \\
1936 & & & & 0.759 \\
Mean & & & 0.463 & 0.731 \\
Median & 0.950 & 0.696 & 0.478 & 0.532 \\
Standard deviation & 0.888 & 0.689 & 0.374 & 272 \\
Number of firms & 127 & 0.303 & 65 & \\
\hline
\end{tabular}


Table 5

Total Assets, 1936

(\$ Thousends)

\begin{tabular}{lcccc}
\hline & Type A & Type B & Type C & All Firms \\
\hline Mean & 119,584 & 43,344 & 32,664 & 76,229 \\
Median & 22,622 & 13,833 & 6,426 & 15,393 \\
Standard deviation & 277,456 & 115,040 & 72,687 & 205,959 \\
Number of firms & 127 & 80 & 66 & 273 \\
\hline
\end{tabular}

Number of firms

77,456

15,040

05,959 
rable 6

Pre-Iax Profit Divided by Book Value of Net Worth, 1936

\begin{tabular}{lcccc}
\hline & Type A & Type B & Type C & A11 Firms \\
\hline Mean & 0.126 & 0.161 & 0.130 & 0.137 \\
Median & 0.099 & 0.124 & 0.100 & 0.108 \\
Standard deviation & 0.095 & 0.106 & 0.094 & 0.099 \\
Number of Eirms & 127 & 80 & 66 & 273 \\
\hline
\end{tabular}


Table 7

Change in Net Operating Profits/Total Assets

\begin{tabular}{|c|c|c|c|c|}
\hline & Type A & Type B & Type C & All $\overline{\text { rirms }}$ \\
\hline \multicolumn{5}{|l|}{1936} \\
\hline $\begin{array}{l}\text { Mean } \\
\text { Median } \\
\text { Standard deviation } \\
\text { Number of firms }\end{array}$ & $\begin{array}{c}0.037 \\
0.029 \\
0.043 \\
127\end{array}$ & $\begin{array}{l}0.059 \\
0.041 \\
0.063 \\
80\end{array}$ & $\begin{array}{l}0.054 \\
0.046 \\
0.068 \\
66\end{array}$ & $\begin{array}{l}0.047 \\
0.038 \\
0.057 \\
273\end{array}$ \\
\hline \multicolumn{5}{|l|}{1937} \\
\hline $\begin{array}{l}\text { Mean } \\
\text { Median } \\
\text { Standard deviation } \\
\text { Number of firms }\end{array}$ & $\begin{array}{l}0.017 \\
0.013 \\
0.048 \\
127\end{array}$ & $\begin{array}{l}0.012 \\
0.006 \\
0.056 \\
80\end{array}$ & $\begin{array}{l}0.007 \\
0.012 \\
0.067 \\
66\end{array}$ & $\begin{array}{c}0.013 \\
0.011 \\
0.056 \\
273\end{array}$ \\
\hline \multicolumn{5}{|c|}{ Net Operating Profits/Sales } \\
\hline \multicolumn{5}{|l|}{1935} \\
\hline $\begin{array}{l}\text { Yean } \\
\text { Median } \\
\text { Standard deviation } \\
\text { Number of firms }\end{array}$ & $\begin{array}{l}0.118 \\
0.097 \\
0.113 \\
121\end{array}$ & $\begin{array}{c}0.111 \\
0.098 \\
0.093 \\
79\end{array}$ & $\begin{array}{c}0.065 \\
0.063 \\
0.081 \\
62\end{array}$ & $\begin{array}{c}0.103 \\
0.090 \\
0.102 \\
262\end{array}$ \\
\hline \multicolumn{5}{|l|}{1936} \\
\hline $\begin{array}{l}\text { Mean } \\
\text { Median } \\
\text { Standard deviation } \\
\text { Number of firms }\end{array}$ & $\begin{array}{l}0.136 \\
0.119 \\
0.079 \\
126\end{array}$ & $\begin{array}{c}0.137 \\
0.123 \\
0.085 \\
79\end{array}$ & $\begin{array}{c}0.101 \\
0.090 \\
0.051 \\
64\end{array}$ & $\begin{array}{c}0.128 \\
0.111 \\
0.077 \\
269\end{array}$ \\
\hline
\end{tabular}


Table 8

Ratio of Market-to-Book Value, 1936 and

Its Percentage Change, 1935-1936

\begin{tabular}{lcccc}
\hline & Type A & Type B & Type C & Al1 Firms \\
\hline 1936 Ratio & & & & \\
Mean & 1.472 & 1.545 & 1.306 & 1.453 \\
Median & 1.216 & 1.260 & 0.980 & 1.247 \\
Standard deviation & 0.977 & 0.913 & 0.897 & 0.944 \\
Number of firms & 127 & 80 & 66 & 273 \\
\&, 1936 & & & & \\
Mean & 0.341 & 0.274 & 0.388 & 0.333 \\
Median & 0.228 & 0.151 & 0.365 & 0.268 \\
Standard deviation & 0.605 & 0.406 & 0.334 & 0.496 \\
Number of firms & 127 & 80 & 66 & 273 \\
\hline
\end{tabular}


Table 9

Ratio of Debt to Market Value of Equity

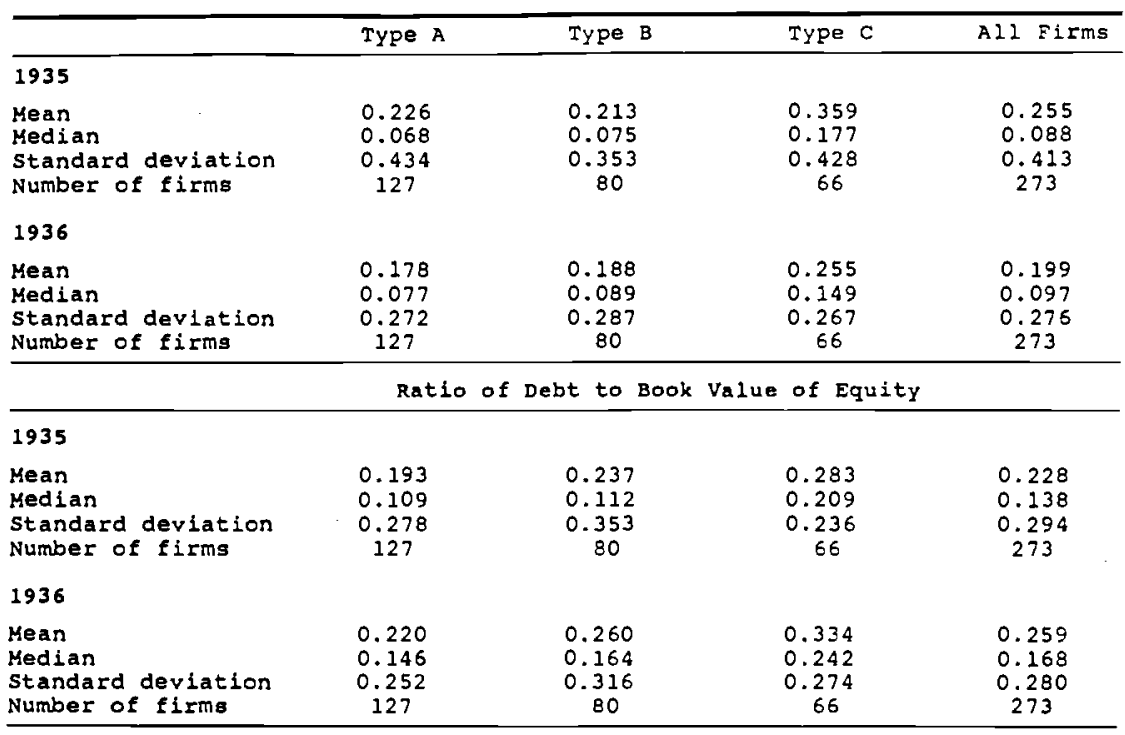


Table 10

Tests of Differences in Kedians Across Firm Types

\begin{tabular}{|c|c|c|c|}
\hline & $\begin{array}{c}\text { Yedians and } \\
\text { Standard Errors } \\
\text { Type A }\end{array}$ & $\begin{array}{c}\text { Medians and } \\
\text { Standard Errors } \\
\text { Type } C\end{array}$ & $\begin{array}{l}\text { E Statistic } \\
\text { for Difference } \\
\text { in Medians of } \\
\text { Types A\& C }\end{array}$ \\
\hline Ioral Assers, 1936 & $\begin{array}{l}22,622 \\
(3,962)\end{array}$ & $\begin{array}{l}6.426 \\
(581)\end{array}$ & 45.11 \\
\hline $\begin{array}{l}\text { Net Operating Profies/ } \\
\text { Sales, } 1935\end{array}$ & $\begin{array}{c}0.097 \\
(0.005)\end{array}$ & $\begin{array}{l}0.063 \\
(0.008)\end{array}$ & 9.71 \\
\hline $\begin{array}{l}\text { Net Operacing Profics/ } \\
\text { Sales, } 1936\end{array}$ & $\begin{array}{l}0.119 \\
(0.006)\end{array}$ & $\begin{array}{l}0.090 \\
(0.005)\end{array}$ & 41.43 \\
\hline $\begin{array}{l}\text { Change in Net } \\
\text { Operating Profits } \\
1935-36 / \\
\text { Total Assets, } 1935\end{array}$ & $\begin{array}{l}0.029 \\
(0.0002)\end{array}$ & $\begin{array}{l}0.046 \\
(0.058)\end{array}$ & 2.39 \\
\hline $\begin{array}{l}\text { Change in Ratio of } \\
\text { Market-to-Book Value, } \\
1935-36\end{array}$ & $\begin{array}{c}0.228 \\
(0.050)\end{array}$ & $\begin{array}{c}0.365 \\
(0.050)\end{array}$ & 18.03 \\
\hline $\begin{array}{l}\text { Debt/Market Value of } \\
\text { Equity, } 1935\end{array}$ & $\begin{array}{l}0.068 \\
(0.009)\end{array}$ & $\begin{array}{c}0.177 \\
(0.041)\end{array}$ & 21.37 \\
\hline $\begin{array}{c}\text { Debc/Book Value of } \\
\text { Equicy, } 1935\end{array}$ & $\begin{array}{c}0.109 \\
(0.019)\end{array}$ & $\begin{array}{l}0.209 \\
(0.034)\end{array}$ & 22.22 \\
\hline
\end{tabular}




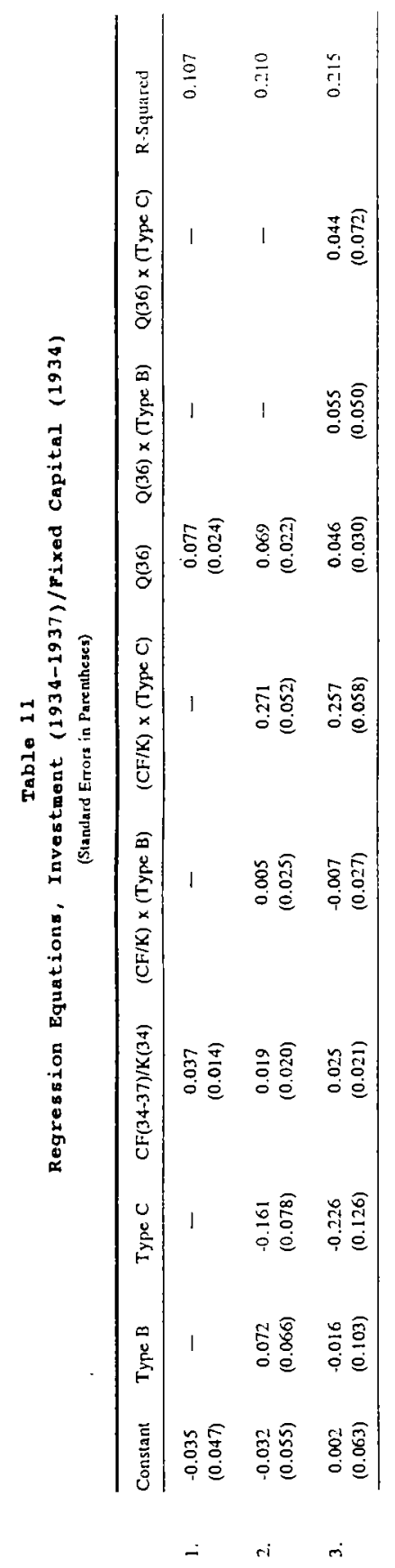




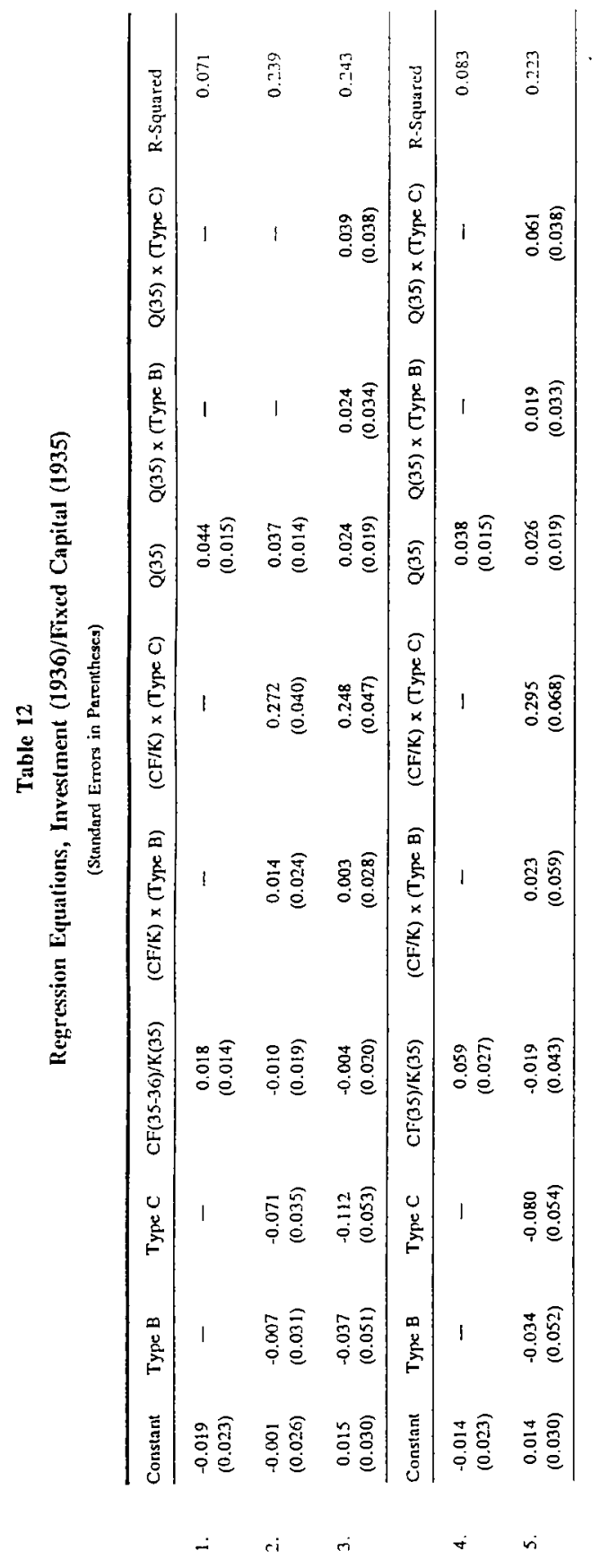


Table 13

OLS Regression, Horking Capltal (1934-1937)/Elxed Capltal (1934)

\begin{tabular}{lcccc}
\hline & Coefficient & $\begin{array}{c}\text { Standard } \\
\text { Error }\end{array}$ & T-Statistics & $\begin{array}{c}\text { Significance } \\
\text { Level }\end{array}$ \\
\hline Constant & 0.076 & 0.130 & 0.584 & 0.560 \\
Type 3 & -0.056 & 0.158 & -0.354 & 0.724 \\
Type C & -0.034 & 0.184 & -0.184 & 0.854 \\
$C F(34-37) / K(34)$ & 0.075 & 0.047 & 1.575 & 0.117 \\
$(C F / K) \times($ Type B) & 0.077 & 0.060 & 1.280 & 0.202 \\
$(C F / K) \times($ Type C) & 0.514 & 0.123 & 4.178 & 0.000 \\
$Q(2936)$ & 0.036 & 0.053 & 0.685 & 0.494 \\
$R^{2}=0.181$ & & & & \\
$\bar{R}^{2}=0.161$ & & & & \\
\hline
\end{tabular}

$C E(34-37) / \mathrm{K}(34)$ - Casin Flow $(1934-37) /$ Flxed Capital (1934).

$Q(1936)$ - Ratio of Market-to-Book Value (1936). 
Table 14

Industrial Composition of Sample Firms

\begin{tabular}{|c|c|c|c|c|c|c|}
\hline \multirow{2}{*}{ Industry } & \multicolumn{4}{|c|}{ Number of Firms } & \multirow{2}{*}{$\begin{array}{l}\text { Fraction of } \\
\text { Firms in } \mathrm{C}\end{array}$} & \multirow{2}{*}{$\begin{array}{l}\text { Capital Growth } \\
1937-48(\%)\end{array}$} \\
\hline & Type A & Type $B$ & Type C & Total & & \\
\hline Apparel & 4 & 0 & 2 & 6 & .33 & 63 \\
\hline Foor coverings & 0 & 3 & 0 & 3 & 0 & 36 \\
\hline Rayon yam & 2 & 1 & 0 & 3 & 0 & \\
\hline Hosiery & 2 & 1 & 3 & 6 & .50 & 11 \\
\hline Textile fabrics & 1 & 4 & 4 & 9 & .44 & \\
\hline Paper and allied products & 3 & 9 & 3 & 15 & .20 & 20 \\
\hline Printing and publishing & 2 & 2 & 3 & 7 & .43 & 3 \\
\hline Newspapers and periodicals & 1 & 2 & 1 & 4 & $.25\}$ & \\
\hline $\begin{array}{l}\text { Construction and mining } \\
\text { machinery }\end{array}$ & 5 & 2 & 1 & 8 & .13 & \\
\hline Metal working machinery & 5 & 4 & 4 & 13 & .31 & 71 \\
\hline General industrial machinery & 10 & 6 & 7 & 23 & .31 & \\
\hline Engines and turbines & 1 & 0 & 2 & 3 & .67 & 184 \\
\hline iron and steet & 6 & 8 & 8 & 22 & .36 & 43 \\
\hline Agricultural machinery & 1 & 2 & 3 & 6 & .50 & 54 \\
\hline Automobiles & 3 & 1 & 1 & 5 & .20 & 44 \\
\hline Chemicals & 10 & 5 & 0 & 15 & 0 & 45 \\
\hline Clgarettes & 4 & 0 & 0 & 4 & 0 & 39 \\
\hline Containers & 4 & 4 & 1 & 9 & .11 & NA \\
\hline Meat packing & 1 & 0 & 0 & 1 & 0 & 2 \\
\hline Office machinery & 5 & 2 & 1 & 8 & .13 & 30 \\
\hline Steel products & 6 & $\overline{1}$ & 3 & 10 & .30 & NA \\
\hline Tires & 1 & 2 & 4 & 7 & .57 & 82 \\
\hline Distllled beverages & 2 & 1 & 0 & 3 & 0 & 32 \\
\hline Paints and vamishes & 0 & 4 & 2 & 6 & .33 & NA \\
\hline Vegetable oils & 2 & 2 & 0 & 4 & 0 & NA \\
\hline Drugs and medicines & 6 & 4 & 0 & . 10 & 0 & 69 \\
\hline Toilet preparations & 3 & 2 & 2 & 7 & .29 & NA \\
\hline Cement & 1 & 2 & 1 & 4 & .251 & \\
\hline Clay products & 2 & 1 & 2 & 5 & $.40\}$ & 8 \\
\hline Building materials & 8 & 2 & 4 & 14 & .29 & \\
\hline Building equipment & 6 & 4 & 3 & 13 & .23 & NA \\
\hline Aircraft & 3 & 1 & 5 & 9 & .56 & 270 \\
\hline Nonferrous metals & 11 & 4 & 1 & 15 & .06 & -21 \\
\hline Oil refining & 13 & 9 & 0 & 14 & 0 & 72 \\
\hline Total & 134 & 87 & 71 & 292 & .24 & 41 \\
\hline
\end{tabular}

Note: The description of Type A Type B, and Type $\mathrm{C}$ firms is given in the lext. Firmtevel information and industry definitions are taken trom Survey of Listod Coporations. Fixed capital stock data used in the calculations in the last column are taken trom Historical Slatistics of the United States Nolume 2, p. 685, Series P 123-i76). 